\title{
112. On the Nutritive Value of Synthetic Fats Containing Oxy-Fatty Acids.
}

\author{
By Junichi Ozaki. \\ Biochemical Laboratory, Faculty of Agriculture, \\ Tokyo Imperial University.
}

(Rec. June 25, 1926. Comm. by Umetaro Suzuki, M.I.A., 12, July 1920̊.)

In continuation to the previous report ${ }^{1)}$ the author carried out the feeding experiment with synthetic fats containing oxy-fatty acids to compare their nutritive value with other kinds of fats. Oxy-fatty acids, except ricinoleic acid, occur in natural fats only in negligible quantity, and so they seem to play only a subordinate role in the animal nutrition. But, according to Knoop, $\beta$-oxy acids are formed as the intermediate products of the successive degradation of long fatty acid chains. Further, the fate of other oxy acids having one or more $\mathrm{OH}$ group at different positions has never been studied thoroughly. The feeding experiments with these fats will therefore contribute something to the knowledge of the fat metabolism in the animal body.

The author has prepared 13 kinds of oxy acids, which were carefully purified and their melting-and boiling-points as well as molecular weights were thoroughly examined.

The preparation of triglycerides from these oxy acids was carried out by means of Twitchell's reagent as described in the first report. ${ }^{1)}$ But, lactin, dioxyundecylin, dioxystearin and trioxystearin could not be prepared by this method, probably these oxy acids being dehydrated and subsequently decomposed by heating with Twitchell's reagent; and so they were previously acetylated and converted into acetylated glycerides.

Beside these synthetic fats, the author used also the mixture of these oxy acids and glycerine. Further more, the nutritive value of ricinolein, acetyl ricinolein and ricinoelaidin were compared one another. The method of feeding used here was exactly the same with that of the former experiment, ${ }^{1)}$ i.e. the young rats were first fed with a limitted quantity of basal diet ( 9 grams per day per rat), and when the growth

1) Proc. Imp. Acad. Vol. II. No. 1, 1926. 
was stopped they were supplied with the test diet containing 5,10 and $20 \%$ of the fats under examination to the basal diet, respectively, and the growth induced thereby were compared each other. These experiments were carried out in the same season, and possibly under the same condition.

The results thus obtained were as follows:

(1) The growth induced by adding $5 \%$ of each fat to the basal diet were shown in the fullowing order:

1. Acetylricinolein $13.5 \mathrm{~g}$

3. Diacetoxystearin $4.5 \mathrm{~g}$

5. 12-Oxystearin $2.5 \mathrm{~g}$

7. Lactic acid and glycerin $1.5 \mathrm{~g}$

9. Monoluctin 1.g

11. Triacetoxystearin *

13. Diacetoxyundecylin*

15. $\alpha$-Oxymyristin ${ }^{*}$

(2) By adding 10\% of each fit:

1. Acetylricinolein $58.5 \mathrm{~g}$

3. Dioxystearic acid and glycerin $19.0 \mathrm{~g}$

5. Diacetoxystearin $18.5 \mathrm{~g}$

7. 0 -Oxystearic acid and glycerin $7.0 \mathrm{~g}$

9. Ricinolein 3.0

11. Trioxystearic acid and glycerin*

13. Triacetoxystearin *

15. Lactic acid and glycerin*

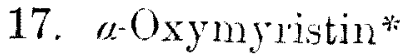

(3) By adding $20 \%$ of each fat:

1. Acetyl ricinolein $63.0 \mathrm{~g}$

3. 12-Oxystearin $16.5 \mathrm{~g}$

5. $\alpha$-Oxystearin $2.5 \mathrm{~g}$
2. Ricinolein $4.5 \mathrm{~g}$

4. a-Oxystearin $3 \mathrm{~g}$

6. $\%$-Oxypalumitin $2 \mathrm{~g}$

S. Trioxystearic acid and glycerin $1.5 \mathrm{~g}$

10. Dioxyundecylic acid and glycerin $1.0 \mathrm{~g}$.

12. Dioxrstearic acil and glycerin*

14. "Oxyheptylin*

16. Ricinoelaidin*

2. 12 -Oxystearin $24.5 \mathrm{~g}$

4. Manolactin $19.0 \mathrm{~g}$

6. axysteatin $17.0 \mathrm{~g}$

8. $a$-Oxy palmitin $4.0 \mathrm{~g}$

10. Dioxyundecylic acid and glycerin*

12. Ricinoelaidin*

14. Diacetoxy undecylin*

16. $\alpha$-Oxyheptylin *

2. Dioxystearic acid and glycerin $18.0 \mathrm{~g}$

4. Diacetoxystearin $4.5 \mathrm{~g}$ 
No. 7.] On the Nutritive Value of Synthetic Fats Containing Oxy-Fatty Acids.

In the above tables, those fats assigned with asteriks* were found to have no nutritive value, and some of them being deciredly noxious. Of special interest is the fact that acetyl ricinolein was far better than ricinolein, and moreover that 12-oxystearin prepared by the hydrogenation of ricinolein gave a higher nutritive value than ricinolein itself.

This might be due to the breaking of the fatty acid chains at different points, yielding thercby different products, which would naturally behave differently in the animal body.

The breaking takes place probably in the following way:-

1) $\mathrm{C}_{6} \mathrm{H}_{13} \mathrm{CH}(\mathrm{O} / \mathrm{H}) \mathrm{CH}_{2} \mathrm{CH}: \mathrm{CH} .\left(\mathrm{CH}_{27} \mathrm{COOH}\right.$

Ricinolein

$\mathrm{C}_{6} \mathrm{H}_{13} \mathrm{CHO}+\mathrm{CH}_{2} \mathrm{CH}: \mathrm{CH} .\left(\mathrm{CH}_{2}\right)_{7} \mathrm{COOH}$

$J^{9}$ Undecyleic acid.

2) $\mathrm{C}_{6} \mathrm{H}_{13} \mathrm{CH}\left(\mathrm{O} . \mathrm{COCH}_{3}\right) \mathrm{CH}_{2} \mathrm{CH}+\mathrm{CH} .\left(\mathrm{CH}_{2}\right)_{7} \mathrm{COOH} \longrightarrow$

Acetylricinolein

$\mathrm{C}_{6} \mathrm{H}_{33} \mathrm{CH}\left(0 . \mathrm{CO} . \mathrm{CH}_{3}\right) \mathrm{CH}_{2} \mathrm{CH}-$

$+\quad-\mathrm{CH}\left(\mathrm{CH}_{2}\right)_{7} \mathrm{COOH}$

3) $\mathrm{C}_{6} \mathrm{H}_{13} \mathrm{CH}(\mathrm{O}, \mathrm{H}) \cdot \mathrm{CH}_{-} \mathrm{CH}\left(\mathrm{CH}_{2}\right)_{7} \mathrm{COOH}$

$\mathrm{C}_{6} \mathrm{H}_{13} \mathrm{CHO}+\mathrm{CH}_{3} \mathrm{CH}_{2} \mathrm{CH}_{2}\left(\mathrm{CH}_{2}\right)_{7} \mathrm{COOH}$

Undecylic acid.

Among the above mentioned pruducts $f^{9}$ undecyleic acid formed from ricinoleic acid is decidedly noxious as proved by the anthor in his former experiment, while others formed from acetylricinolein and 12-oxystearin have no noxious effect at all.

It seems that the breaking of the molecules occurs at first, at the point where $\mathrm{OH}$ group is attached or where double linking is present.

Summary of the Results.

1) The nutritive value of the fats containing oxy-fatty acids differs according to the position of $\mathrm{OH}$ group. Thus, for instance, $\alpha$ - and 12-oxystearin were found to have quite different values.

2) The fats containing $\alpha-0 x y$ acids are inferior to those of the corresponding saturated fatty acids, so it is improbable that a-oxydation occurs in the animal body. 
3) The noxious effect of certain a-oxyacids decreases with the increase of the molecular weights. Thus for instance, $\alpha$-oxyheptylin and o-oxymyristin have stronger toxicity than a-oxypalmitin or a-oxystearin.

4) The nutritive value of oxy acids depends on the position of $\mathrm{OH}$ group, rather than the number of $\mathrm{OH}$ groups in the molecule.

5) The nutritive value of ricinolein is greatly improved by acetylation, but as to dioxyundecylin, dioxystearin and; trioxystearin, the acetylation had little effect upon the nutritive value.

6) The improvement of the nutritive value of ricinolein by acetylation or hydrogenation may be due to the formation of different products by breaking of its molecule.

7) Ricinolein was found to be better than its solid isomer, ricinoelaidin. 